\title{
A comparative assessment of the agency concept, with special regard to the Romanian approach
}

\author{
Professor Ioan SCHIAU ${ }^{1}$ \\ Motto: Non idem est si duo dicunt idem
}

\begin{abstract}
The concept of agency was developed and refined in the common law system and, thereafter, imported in the continental civil law system where was confronted with the classic institution of the mandate, based on the representation principle. The modern context of the commerce globalisation and the need to assimilate legal instruments that are often used in the international trade, determined the global and European lawmakers to seek a proper harmonised regulation for the agency contract. Romania produced a first regulation of agency through Law 509/2002 regarding the permanent commercial agents and, thereafter, continued the process through the incorporation of the subject in the Civil Code. This paper examines the conformity of the European and Romanian regulations regarding the agency with the initial concept that, purportedly, inspired the afore said lawmakers.
\end{abstract}

Keywords: agency, authority, mandate, representation.

JEL Classification: K12, K15

DOI: $10.24818 / \mathrm{TBJ} / 2021 / 11 / 2.05$

\section{A brief introduction to agency}

Historically speaking, the practice of agency developed in England, in the Middle Age. As well as some other individual employment relations, ${ }^{2}$ apparently the agency is an evolution of the law of master and servant that implied a relation between the master of the household and a designated servant, marked by obedience of the servant, which was bound to obey and execute the orders of the master against a wage and/or other facilities granted to him. ${ }^{3}$ The agent was either acting for his

\footnotetext{
${ }^{1}$ Ioan Schiau - full professor of commercial law at the Faculty of Law of Transilvania University of Brasov, Romania. Prof. Schiau is, also, a founder and managing partner of Schiau, Prescure, Teodorescu, Crisan Law Office and acts frequently as arbitrator in various commercial disputes, schiau@schiau-prescure.ro.

2 Jenks, C. Wilfried, Human Rights and International Labor Standards, London: Stevens \& Sons; New York: Praeger, 1960, „American Journal of International Law”, 56(3), 880-881. Accessed 21.01.2021, doi: 10.2307/2196536, published online by Cambridge University Press: 28 March 2017.

${ }^{3}$ Müller-Freienfels, Wolfram, Legal Relations in the Law of Agency: Power of Agency and Commercial Certainty, „The American Journal of Comparative Law”, Volume 13, Issue 3, Summer 1964, p. 341359, accessed 21.01.2021, https://doi.org/10.2307/838680. According to this author: "Anglo-Norman law created the figures of ballivus and attornatus. His position in the household of his master empowered the ballivus to transact commercial business for his master, reminiscent of the power of the slave to bind his master under Roman law. Later the ballivus was given more authority, especially in his frequent role as land administrator, gradually becoming competent to act independently for his
} 
master, mainly as a land administrator (ballivus), either representing his master in litigation or in concluding certain solemn contracts or deeds (attornatus), the latter being the architype of the nowadays general agent.

The concept of agency was further developed in English law due to the independence gained by the commercial law, which, during the $18^{\text {th }}$ century separated from the common law core body, and produced the concept of undisclosed agency, "an especially important mode of representation in commercial transactions, in which the agent appears to be the principal". ${ }^{4}$ The undisclosed relation of agency, while concealing the identity of the principal, was not, however, a reason for rejection of claims of the third contractors, directly addressed to him.

Meanwhile, starting with the $16^{\text {th }}-17^{\text {th }}$ centuries, the concept of agency penetrated the continental Europe system of civil law and the representation principle was codified through the French (or Napoleon) Civil Code in 1804, wherefrom it was successfully exported throughout all Europe. But these continental legislations, nevertheless, regarded the agency as an expression of the mandate, which was an established and well-known institution, based on Roman law. Accordingly, the person that was acting through another one, was acting as if he were doing it himself, thus the agent needed to act openly in the name of the principal to produce the desired effects of his agency.

So, during the last centuries, both the English commercial law and the continental civil law were regulating the concept of agency, sheltering under the same term quite different representations and contractual structures.

\section{The core of the agency in the English commercial law}

As early as the $18^{\text {th }}$ century, agency started to play an important role in the commercial transactions and became an important feature of commercial life in various fields. For instance, the first advertisement agency was presumably established in $1786,{ }^{5}$ the first real estate agency was established in 1805 (and is still active today $)^{6}$ while the first travel agency was established in $1841,{ }^{7}$ all being situated in London.

The concept of agency, in the English commercial law is a broad one and before the implementation, in 1993, of the Directive 86/653/EEC was largely based

master. On the other hand, the attornatus, originally just a representative of one of the parties in litigation, soon assumed a position of broader importance. Certain contracts were effective only when made in a judicially prescribed manner. For this reason, the formation of this type of contract always had to be concluded in a court proceeding in which an attornatus represented each party. This was the beginning of the role of the attornatus as a general agent."

${ }^{4}$ Müller-Freienfels, Wolfram, op. cit, 1964, p. 341-359.

${ }^{5} \mathrm{https}$ ://www.campaignlive.co.uk/article/history-advertising-no-84-worlds-first-ad-agency/1220515, accessed 29.01.2021

${ }^{6} \mathrm{https} / /$ www.estateagenttoday.co.uk/features/2017/8/property-natter--a-short-history-of-estateagency, accessed 31.01.2021

7 https://www.ctheworld.co.uk/blog/a-brief-history-of-the-travel-agent, accessed 31.01.2021; the first travel agency in London was Thomas Cook Agency. 
on precedents, a traditional source of law in the common-law system ${ }^{8}$ actually, the concept of agency covers almost any issue of employment of a person by another one, accidentally or in a steadfast manner, for a salary or for a commission. That practical approach allows for a wide range of hypostases of an agent and of the relationships that bound the agent to the principal. ${ }^{9}$

The commercial doctrine revealed that even the role and the positions of the management of the corporation is rooted in the agency principles, since in the $19^{\text {th }}$ century the directors of a company were merely seen as being the agents of the company's shareholders ${ }^{10}$.

It is commonly agreed that, as a general rule, an agent may act on a disclosed agency agreement or based on an undisclosed agency agreement. While a disclosed agency seems to produce effects similar to the mandate of the civil law system, the undisclosed agency is close to the commissioning contract of the civil law, a variety of the mandate, where the agent contracts in his own name without disclosing his principal, although it is acting on his account ${ }^{11}$.

Nevertheless, the undisclosed principal is not protected against the third contractors, which may sue the principal or be sued by the principal, if the agent had power to make contracts for the principal and if the third party, eventually, learn the identity of the occulted principal. That consequence is based on the theory of identity of principal and agent, which became the theoretical foundation of agency and is expressed through the Latin syntagma qui facit per alterum facit per se $e^{12}$ (the agent being viewed as the intermediary through which the principal is performing his acts $)^{13}$.

Under the English law of agency, it seems that the key notion that defines the powers invested by the principal in the agent is "authority". The notion is used in various contexts. For instance, the agent is authorised by the principle; his authority may be express or implied; his authority may be restricted or generally, as to cover only some acts (like a sale of goods or borrowing money on behalf of a

\footnotetext{
${ }^{8}$ The author of this paper, being educated in the continental civil law system, is examining the English concept of agency from an external perspective, pointing out, inevitably, the main issues that separate this concept from the imported continental concept of agency, which is still influenced by the mandate rules.

${ }^{9}$ Anyhow, while in 1986, the European Communities enacted Directive 86/653/EEC on self-employed commercial agents and the United Kingdom implemented this directive through "The Commercial Agents (Council Directive) Regulations 1993", this did not change essentially the regime of agency in English. Law. Both the Directive and the Regulation 1993 are similarly structured, addressing the conclusion and the termination of the agency contract, the rights and obligations of the agent and of the principal and the remuneration of the agent but did not concern the structure of the relationship of both parties and the sources of the agent powers or the authority enjoyed by the agent.

${ }^{10}$ Dignam, Alan, Lowry, John, Company Law, Oxford University Press, 2006 p. 255-256.

${ }^{11}$ Martin, Elizabeth A. (editor), Oxford Dictionary of Law, Oxford University Press, 2003, p. 19-20.

${ }^{12}$ Meaning that "He who does an act through another is deemed in law to do it himself".

${ }^{13}$ Schmitthoff, Clive, Agency in International Trade. A study in Comparative Law, Hague Academy of International Law, 117 Recuil des Courts, 1970-1, at 115 et seq., https://www.translex.org/128700/mark_911000/, accessed 3.02.2021.
} 
principal) or a multitude of acts (like to do all things relating to the business of the principal) ${ }^{14}$.

The agent may act on an express authority or an apparent authority. ${ }^{15}$ The express authority results from a contract or agreement that underline the parties' rights and obligations (internal contractual relationship) and, consequently, the power vested in the agent, i.e., the authority given to the agent, is based on a relation or consent between the principal and the agent. The apparent authority is conferred by the principal causing third persons to believe that the agent has authority to conclude contracts for him and determining the third parties to act upon an agent's ostensible authority. That means that the apparent authority is not the result of principal's and agent's agreement, but the result of principal's behaviour in relation with the third parties; a representation made by the principal in respect of the agent's authority, relied upon by third parties that performed an act based on that representation are the indispensable features of the apparent authority. Consequently, the principal is not liable if the apparent authority was not created by him or is not the result of his conduct.

It is generally considered that an agency relationship is based on authority resulting from the parties' consent (expressed or implied) that the agent will act on principal's behalf and under his control. When the authority granted to the agent is limited, his powers are restricted to the limits of the principal's consent and cannot be further extended, exception being made for those powers required or adequate to carry out the said authority.

Since the agent's authority may be express or implied, it not requires a written instrument as proof of agency, which may also be construed as having a factual existence. Since the apparent authority is based on principal's behaviour that created the appearance of authority, absence of a written instrument cannot benefit to the principle that mislead third parties to act on that apparent authority.

Following this incursion in the legal regime of agency in the English commercial law - that inspired, as well, the American approach to this institution one should make a distinction between actual authority (based upon an agreement between the principal and the agent - an internal relationship) and the apparent authority, which is a result of an external relationship, between the principal and the third party. This, once again, emphasises that the concept of "authority" is the main foundation of the agency construction.

More, it is obvious that the agent is acting on behalf and under the control of the principal but not, inevitably, in the name of the principal; actually, the English

${ }^{14}$ Baskind, Eric, Osborne, Greg, Roach Lee, Commercial Law, $3^{\text {rd }}$ ed., Part. II: The Law of Agency, Oxford University PressPrint Publication, Date: Apr 2019 Print, published online: Sep 2019 DOI: 10.1093/he/9780198825975.001.000, accessed 31.01.2021.

${ }^{15}$ The agents may, also, enjoy an implied authority, i.e., the authority to perform acts that are implicitly linked to the exercise of their actual or apparent authority as well as an inherent authority, which exceeds the scope of their authority but cannot be discerned by a third party from the actual authority. For instance, an agent entrusted with the authority to sell goods on the market has also the authority to advertise such sale (implied authority) but may not have the authority to sell on credit; when the agent is so doing, third parties may consider that such authority is inherent to the powers of the agent. 
commercial does not make this distinction (that it is important in the continental law of mandate) between an agent acting on behalf of the principal (but in its own name) and the agent that it is acting on behalf and in the name of the principal. ${ }^{16}$

And finally, the agency and the authority resulting from it are not, necessarily, expression of a long-lasting relationship between the principal and the agent.

These brief conclusions are important when comparing the concept of agency, as it was born and refined in England, with the regulation of the agency, as it was imported in the continental system of civil law.

\section{International legislation}

In 1983, under the umbrella of the United Nations, a number of 58 states adopted in Geneva the Convention on Agency in the International Sale Contracts (hereinafter, the Convention), aiming to establish common provisions applicable to the agency in the international trade.

Without offering a legal meaning to the agency, which is, anyhow, a concept difficult to define, Article 1(1) of the Convention states that it applies "where one person, the agent, has authority or purports to have authority on behalf of another person, the principal, to conclude a contract of sale of goods with a third party". Apparently, compared with the traditional agency concept, the Convention assumed a slightly different approach in relation to the apparent authority of the agent: according to the Convention, the agent's authority is a real one or one purported by the agent. Therefore, while the English concept of the apparent authority is based on the principal's behaviour, the Convention's concept is structured on the conduct of the agent, which is the one claiming the existence of the authority. In other words, while the English concept regards the apparent authority of the agent from the principal's perspective, the Convention reflects the same notion from the agent's perspective.

According to Article 1(4), the Convention applies irrespective of whether the agent acts in his own name or in that of the principal; by stating that it applies in both hypotheses, the Convention is making, nevertheless, an express distinction between the acts performed by the agent on behalf and in the name of the principal and the acts performed on behalf of the principal but in the agent's own name, a distinction more properly located in the civil system of law that regulates the mandate. Anyhow, according to Article 12 of the Convention, whenever the agent acts on behalf of a principal within the scope of his authority and the third party knew or ought to have known that the agent was acting as an agent, the acts of the agent shall directly bind the principal and the third party to each other. That effect will not occur when, from the circumstances of the case (for example, by a reference to a contract of commission), results that the agent undertakes to bind himself only.

${ }_{16}$ Markesinis, Basil, Munday, Roderick, Outline of the Law of Agency, $2^{\text {nd }}$ ed., London 1986, pp. 114-168. 
Articles 9 and 10 of the Convention outline other critical features of the agency in international sale of goods: the authorisation of the agent by the principal may be express or implied (purported by the agent) and need not to be given or evidenced in writing. The agent has authority to perform all acts necessary to achieve the purposes for which the authorisation was given by the principal, but such an authorisation may regard the performance of a singular act, or a plurality of acts indicated by the principal, to be performed by the agent. That means that the agent is not necessarily designated to act on a long-term basis.

However, Article 12 and Article 13 of the Convention record different effects of the contract concluded by the agent with the third party, pending on two distinct premises:

(a) If the third party knew or should have known that the agent is acting on behalf of the principal, the effects of the contract of sale occur directly between the principal and the third party, unless reference is made to a commission contract, or it appears that the agent oblige in one's own name;

(b) If the third party did not know and should not have known that the agent is acting as an agent (i.e., on behalf of another person) or the agent has made special reference to a commission contract, then the effects of the contract occur directly between the agent and the third party.

As a conclusion, the concept of agency promoted by the Convention reveals close connection with its English model, making a distinction between the actual and implied (apparent) authority of the agent; nevertheless, the Convention makes a distinction between the agent acting on the name of the principal and the agent that is acting in its own name, but on behalf of the principal.

\section{The European law}

In 1986, the European Communities enacted Directive 86/653/EEC (the Directive) on self-employed commercial agents. According to the Directive, which does not offer a definition of the agency, "commercial agent" shall mean a selfemployed intermediary who has continuing authority to negotiate the sale or the purchase of goods on behalf of another person, hereinafter called the "principal", or to negotiate and conclude such transactions on behalf of and in the name of that principal [Article 1 (2) of the Directive].

There are some interesting features that the Directive, indirectly, brought to the concept of agency: the agent is acting independently, the agent is an intermediary, the agent is enjoying continuing authority and the agent may act both on behalf of the principal and on behalf and in the name of the principal.

The agent described by the Directive is an independent person (a selfemployed person) that is under the authority and control of the principal, but it is not an employee or (if the principal is a corporation) it is not an officer of the principal. On the contrary, based upon the master and servant doctrine, the agent was initially, under the English commercial law, a person dependent of the principal. 
The agent is an intermediary, which intervenes in the circulation of goods and values and facilitates the negotiation and the conclusion of transactions between the principal and the third parties.

As a particular feature of his physiognomy, the agent is enjoying continuing authority to perform certain acts on behalf of the principal; he is not, anymore, an ephemeral figure acting incidentally on behalf of the principal, but a person that is linked to the principal with long-standing commitments that usually cover a wide array of duties.

As a notable limitation, the scope of the agent's authority, as envisaged by the Directive, is limited to the sale and purchase of goods, very similar to the one regulated by the Convention. There is no explanation for such restriction in the recitals of the Directive that are using the notion of "commercial transactions" and "trade in goods", which seem to offer a wider display of activities than the simple sale or purchase of goods.

Like the Convention, the Directive is making a distinction between two hypostases of the agent acts, a distinction with no significant relevance in the English commercial law; the agent may have authority to negotiate on behalf of the principal, or to negotiate and conclude contracts on behalf and in the name of the principal. The attempt to determine the scope of the agent's authority through interpretation of the provisions of Article 1 of the Directive, reveals that an agent that has authority to negotiate for the principal will act on his behalf (that may be on behalf and in the name of the principal or on behalf of the principal but in its own name) while an agent trusted to negotiate and conclude transactions for the principal will act on behalf and in the name of the principal. As an apparent consequence, when the agent has the authority to conclude sale contracts for the principal, he is only allowed to do so on behalf and in the name of the principal. Therefore, that kind of authority may be assimilated with a perfect or direct representation of the principal by the representative, an institution well known in the continental system of law.

By introducing that distinction between the above mentioned two hypostases of the agent, the Directive is attempting to conciliate the continental civil law concept of representation (direct or indirect) with that of the authority (actual or apparent) that is the source and expression of traditional agent's powers.

\section{National legislations}

A. France. The initial law governing the agency in France was a Decree dated December 23, 1958, which, notably, organized a registration process for the commercial agents, as a precondition to obtain a professional statute. The Law no 91-593/1991 regarding the relationship between the commercial agents and their principa $1{ }^{17}$ has transposed in the French national law the provisions of the Directive. The Law was repelled in 2000, through Ordinance no. 2000-912 regarding the legislative part of the commercial code (which incorporated those provisions).

\footnotetext{
17 The Law was repelled in 2000, through Ordinance no. 2000-912 regarding the legislative part of the commercial code.
} 
Article 1 as well as the title of the Law of 1991 leave no doubt about the sources that inspired the French lawmaker (besides, purportedly, the text of the Directive): the agent is a representative (in French: mandataire) while the principal is the represented person (in French: mandant). Article L134-1 is taking over from the repelled Law and uses the same terminology: the agent is a representative, a mandatory (in French: mandataire), acting as an independent professionel which, without being bound by an employement contract, is in a permanent position to negotiate and eventually to enter into various contracts on behalf and in the name of the principal (producer, suplier, trader, merchant or other commercial agent).

It is then obvious that the agency is based on a representation relation, where the authority of the agent is an expression of the mandate given to him. ${ }^{18}$ In this respect, the French doctrine reported that there is a fragile delimitation between the commercial agents and the managers of a corporation that are also able to represent the legal person, based on a similar mandate. ${ }^{19}$

B. Italy. The contract of agency was regulated, for the first time, in the Civil Code of 1942; the Civil Code was amended in 1985 in order to transpose the Directive into Italian law. According to Article 1742 of Civil Code, the agent assumes the constant assignment to promote, on behalf of the principal, the conclusion of contracts in a determined zone.

Article 1752 of the Civil Code mentions that the principal may grant to the agent representation powers, by that pointing out the figure of the commercial agent or of the representative agent (in Italian: agente con rappresentanza) that is empowered to conclude contracts on behalf and in the name of the principal. The agent may choose to use or not these powers of representation but, if he does so, he has the obligation to notify the third-party contractor that it is acting on behalf and in the name of the principal. ${ }^{20}$

The agent is acting independently, on a constant basis, against an agreed indemnity. The agent is not an employee and it is not a mandatory, which is appointed to fulfil legal functions rather than commercial ones. ${ }^{21}$

Consequently, the agency regulated by the Civil Code is dedicated mainly to the promotion of the conclusion of principal's transactions and, only on a second layer, to represent the principal in conclusion of such transactions.

C. Spain. The contract of agency, which was not regulated by the Code of Commerce, is subject to Law no. 12/1992 that transposed the Directive into Spanish law but also gave to the contract a complete legal regime. The Spanish lawmaker defines the agency as that contract through which the agent is assuming the continued and stable obligation to promote commercial acts and operations on behalf of the principal or to promote and conclude such commercial acts and operations on behalf

${ }^{18}$ Reinhard, Yves, Thomasset-Pierre, Sylvie, Droit commercial. Actes de commerce. Commerçants. Fonds de commerce. Concurrence. Consommation., Litec, 2008, p. 249.

${ }^{19}$ Cozian, Maurice, Vivandier, Alain, Droit des sociétés, Cinquième Edition, Litec, 1992, p. 114.

${ }^{20}$ Fiale, Aldo, Diritto Commerciale. XVII edizione, Edizioni Giuridiche Simoni, 2006, p. 993 et seq.

${ }^{21}$ Dobson, David. M., Gaudenzi, Rita, Agency and Distributorship Laws in Italy: Guidelines for the Foreign Principal, „The International Lawyer”, vol. 20, no. 3, American Bar Association, p. 998 et seq. 
and in the name of the principal. The definition is completely in line with the concept of agency promoted by the Directive, but unlike the Directive, it is not restraining, to the sale or purchase of goods, the commercial acts and operations carried by the agent.

Initially, the contract was categorised as a sub-specie of the commission contract but the recent doctrine ${ }^{22}$ considers that the agency contract has its own identity, distinct of the commission contract, due to its permanent, long-time duration (while the commission has an irregular, sporadic character) and due to the fact that the agent may conclude contracts in the name of the principal.

D. Germany. According to the German Commercial Code (Article 84) a commercial agent is anyone who, as an independent trader, is permanently entrusted with promoting business for the principal either as an intermediary or in the principal's name, without being an employee in the principal's establishment. The agent is a professional, since same text is requiring him to attend to his principal's business with the diligence of a careful commercial trader.

The Commercial Code is regulating, therefore, two hypostases of the agent: the one who is acting as an intermediary, on behalf of the principal, his duty being to mediate and promote the business of the principal, and the one who is acting on behalf and in the principal's name, negotiating and concluding transactions for the latter often in a delimitated territory (district agent). ${ }^{23}$

While the acts of the agent that is entrusted to act in the name of the principal are considered to be principal's own acts, if an agent who is only empowered to act as an intermediary, enters upon a transaction with a third party in the name of his principal, that transaction shall be deemed to be ratified by the principal unless the latter, immediately upon being informed of it, expressly repudiates it by notice to the third party.

E. Switzerland. Not being a member of EU, the Swiss state has no obligation to transpose the Directive. ${ }^{24}$ The agency is regulated by the Swiss Code of Obligations (CO), which in Article 418a defines the agent as a person who undertakes, on a permanent or part time basis, to negotiate the conclusion of business for one or more principals (application agent) or to conclude business on their principal's behalf, without being dependent on a contract of employment with the principal (underwriting agent). ${ }^{25}$ If the agent is instructed to conclude business

22 Jimenez Sanchez, Guillermo J, Lecciones de Derecho Mercantil, Decimoquinta Edicion, Tecnos, 2012, pp. 453-454.

${ }^{23}$ Groh, Dennis, German Commercial Agency Law at a Glance, Cologne, Germany https://www.dapjv. com/relaunch/wp-content/ uploads/2019/11/DAPJV-GAPLA-German-commercial-agency-law-ata-glance.pdf, accessed 9.02.2021

${ }^{24}$ Nevertheless, in 2002, Switzerland and EU concluded an agreement under which Switzerland is to be treated as a Member State within the meaning of the Directive.

25 Jausas, Augustin (editor), International Encyclopaedia of Agency and Distribution Agreements, Wolters Kluwer Law \& Business, 2012, p. 174. 
transactions on behalf of third persons, the provisions governing the commission contract will also apply (Article $418 \mathrm{~b} \mathrm{CO}){ }^{26}$

According to Article $396 \mathrm{CO}$, unless expressly defined by the contract, the scope of the agency is determined by the nature of the business to which it relates and includes the authority to carry out such transactions as are required for diligent and faithful performance of the contract. In order to agree a settlement, accept an arbitration award, contract bill liabilities, alienate or encumber land or dispose of the principal's goods, the agent requires a special authority.

Form the above-mentioned provisions, it results that, in fulfilling the authority given to him - which includes conduct of principal's business and provision of services, the agent will act as agreed and instructed by the principal, either on behalf of the principal, either on behalf and in the name of the principal.

Therefore, the Swiss regulation of the agency is providing for an independent, professional agent, working on a continuing relationship ${ }^{27}$ and enjoying an authority that allows him to act in a diversity of legal positions, based on the internal relationship resulting from the agency contract.

F. Partial conclusions. Mostly of the European national legislations regarding the agency were adopted in order to transpose the Directive in the domestic system of law. Nevertheless, the agency is considered as being very close related to the mandate contract and the concept of authority is, often, replaced with that of representation, which is more familiar to the continental system of civil law.

\section{Romanian legislation}

In Romania, the agency contract was, for a long time, an unnamed contract, used as an international commercial contract and studied exclusively by the doctrine of international trade law, which has revealed its complex legal nature and main features and effects. ${ }^{28}$

The first legal enactment that regulated the agency is Law no. 509/2002 regarding the permanent commercial agents, purportedly aiming not only to merely incorporate Directive 86/653/EEC but also to adopt its rules to the Romanian juridical realities. The law defined the agent as an independent intermediary, who is permanently empowered to negotiate business for another person, called the principal, or to negotiate and conclude business in the name and on behalf of the principal. Basically, this definition is a true translation of Article 1(2) of the Directive, covering both the authority/mandate of the mandatory with representation and that of the mandatory without representation.

26 Albaric, Cristelle, Dickstein, Marianne, International Commercial Agency and Distribution Agreements: Case Law and Contract Clauses, Kluwer Law International B.V, 2017, Chapter XVI Switzerland.

27 If it is working on a case-to-case basis, the person will be a broker and not an agent. The brokerage contracts are regulated by Article 412 et seq. CO.

${ }^{28}$ Schiau, Ioan, A Fragile Construction. A Critical Review of the Current Regulation of the Agency Contract, ,Revista Română de Drept Comercial”, no. 3/2020. 
In the context of the unification of the Romanian system of private law (2009-2011), Law no. 509/2002 was abrogated and the agency contract was given a new regulation, through the provisions of the Civil Code, which also gave it a new definition. Article 2072 (1) of Civil Code defines the agency as the contract by which the principal ${ }^{29}$ permanently empowers the agent either to negotiate or both to negotiate and to conclude contracts, in the name and on behalf of the principal, in exchange for remuneration, in one or more specific regions. ${ }^{30}$

A comparation between the authority enjoyed by the agent according to the Convention and the Directive reveals that the Romanian lawmaker departed from the agency concept promoted by these two international regulations. According to the Convention and the Directive, the agent may have authority to negotiate on behalf of the principal, or to negotiate and conclude contracts on behalf and in the name of the principal, by that making a subtle distinction between the situations when the agent may act on behalf of the agent (and in the name of the principal or in its own name) or only on behalf and in the name of the principal.

By simply omitting some words, the Romanian Civil Code states that the agent is empowered either to negotiate or both to negotiate and to conclude contracts, in the name and on behalf of the principal. The drafting of this phrase is allowing only one conclusion: that, under the Romanian law, the agent is acting, always, in the name and on behalf of the principal, which means that he enjoys full, direct representation of the principal and that the contracts concluded by the agent are always the acts of the principal (qui facit per alterum facit per se).

To complete the configuration of the contract, Article 2072 (1) of Civil Code shows that the agent is an independent intermediary, acting on a professional basis and that he is not and cannot be, at the same time, the principal's employee. More, Articles 2095(1) and 2095(2) of the Civil Code add that, in so far as compatible, the provisions relating to the commission contract are, also, applicable to the agency and that, if the agent has the power to represent the principal at the conclusion of contracts, the provisions concerning the mandate with representation will be, also, applicable.

The conclusion drawn from the assessment of these legal provisions is somehow disconcerting; whenever the provisions governing the commission contract are applicable, the agency is transformed in a sub-specie of the commission contract; whenever the mandate rules are applicable, the agency becomes a subspecie of the mandate contract. It results that under the Romanian Law, the agency is strongly impregnated with features that are specific to the mandate and that the law regards the agency contract as a specie of the mandate rather than a stand-alone contract. ${ }^{31}$

${ }^{29}$ Actually, the Romanian lawmaker opted, instead of the term "principal", for the term "comitent" which is the Romanian equivalent of "commetant", the term used in the French version of the Directive.

${ }^{30}$ For a doctrinaire definition, see Cărpenaru, Stanciu D., Tratat de drept comercial român, $4^{\text {th }}$ edition, Universul Juridic Publishing House, Bucharest, 2014, p. 570.

${ }^{31}$ Nemeș, Vasile, Fierbințeanu, Gabriela, Dreptul contractelor civile și comerciale. Teorie, jurisprudență, modele., Hamangiu Publishing House, Bucharest, 2020, p. 440 et seq. 
Deconstruction of the agency concept, as regulated by the Romanian Civil Code shows that the agent, which, according to Article 2072, is acting on behalf and in the name of the principal, may, notwithstanding these provisions, act sometimes, without representation, as a commissioner (according to Article 2095 of the Civil Code).

Such conclusion is also supported by the logical, systematic interpretation of Article 2080(3) of Civil Code; according to this text, the principal must inform the agent, within a reasonable time, regarding the acceptance, refusal or nonexecution of a contract negotiated or, as the case may be, concluded by the agent. Should the agent conclude contracts only in the name and on behalf of the principal, as the indicated by Article 2072 of the Civil Code, then the provisions of Article 2080(3) of the Civil Code would be meaningless. Since the agent would always act with perfect representation on behalf of the principal, the effects of the agent's contract would have a direct effect on the principal, without the latter having the option to accept or refuse the agent's contract or performance. Therefore, rejection of the contract concluded by the agent in the name of the principal would amount to the unilateral termination of a valid contract and would give rise to the right of the third party to call for the liability of the principal, the one with whom (by representation) the third party concluded the said contract.

On the contrary, when the agent concluded the contract in his own name, but on behalf of the principal, Article 2080(3) of the Civil Code is consistent with Article 2048(4) of the Civil Code, according to which any operation of the commissioner, in violation of or exceeding the powers received, remains in his charge, unless it is ratified by the principal.

Since the agent, according to the concept embraced by the Romanian lawmaker, is either a commissioner either a mandatory enjoying direct representation, the only visible and remarkable features of the agency contract are granted by the fact that the agent is acting on a permanent and professional basis, independently and in one or more specific regions.

The agent is acting on a continuing, long-time relationship established with the principal in respect of a wide range of acts and operations: negotiation and/or negotiation and conclusion of sale purchase contracts, service contracts and other commercial contracts. In that respect, agents are distinct from brokers and other accidental intermediaries, since they do not act occasionally, but permanently, over a long period of time. ${ }^{32}$

The agent is a professional, a person that, according to Article 3 of the Civil Code, is exploiting an enterprise that is a systematic, organized commercial activity. Such a person is usually organised as a legal person, although the law does not restrict natural persons to become agents.

The agent is acting independently, although it is performing his contractual duties according to the instructions of the principal and under the control of the

32 DiMateo, Larry A., International Contracting: Law and practice, Kluwer Law International B.V., 2016, p. 768. 
principal. The agent is not an employee of the agent or otherwise dependent person in relation with the principal.

And finally, the agent's activity is restricted to certain areas; such restriction imply that the principal may use several agents allocated, geographically, to distinct regions and that the gent may enjoy exclusivity in the regions allocated to him.

On a final count, it seems that the agency, as regulated by the Romanian Civil Code, looks too much alike to a species of the mandate, the characteristic intermediation contract regulated by the continental civil law system. Lacking an extensive understanding of the "authority" concept, the cornerstone of the agency in the English commercial law, the Romanian lawmaker opted to give new clothes to a familiar institution, that of the mandate.

\section{Conclusions}

The agency concept was born and crafted in the practice of the English merchants and refined by the precedents established by the English courts, benefitting of the absence of the rigid requirements of the continental civil law system; therefore, it has been construed as a complex but supple legal instrument in contrast with the models provided by the continental civil law (the mandate) or commercial law (the commission and other related contracts).

While the civil law instruments used for the intermediation of the principal's business are based on representation (either full, direct representation - the mandate or imperfect, indirect representation - the commission), the agency under English commercial law is a mechanism based on authority, either actual or apparent. Although it has made efforts to assimilate the agency concept, the continental system of law is still tributary to the representation, as the base of the mandate, and has difficulties to assume the "authority" concept, which has roots in the common law system, so different from the civil law system.

It is noteworthy, in the context, that in both systems, the agent may act in a twofold posture. According to the English or Anglo-American approach, an agent may act on actual authority (based on a consensus between the principal and the agent) or on apparent authority (agency by estoppel - based on the behaviour or the conduct of the principal). Likewise, the agent governed by the continental civil law may act on perfect or direct representation powers, specifically entrusted to him by the principal, or on indirect representation, when is acting in its own name, but on the behalf of the principal, mainly in the area of promoting the business of the principal and negotiating for him.

More, the legal character of the traditional agent working on the base of an undisclosed agency is very similar to that of the commissioner that, in the civil law system, works on behalf of the principal but on its own name. ${ }^{33}$

Besides these similarities, there are many distinctions between the concepts of agency embraced by the two law systems. For instance, the mandate of the

33 Busch, D., Indirect Representation and the Lando Principles, vol 2.3, „Electronic Journal of Comparative Law", (December 1998), <http://www.ejcl.org/23/art23-1.html>. 
European agent is a continuing one, the internal relationship of the agent and the principal being one that is extended over a long period of time; the traditional agent's authority may be extended for a long-time or may be occasionally granted, for a single transaction.

Further, according to the English commercial law and practice, the principal is liable for an agent that is acting outside his authority or on apparent authority, if it has created, expressly or by his conduct, to the third persons, the conviction that the agent enjoys the authority to act so. On the contrary, in the civil law system, the principal is liable for the acts or activities of the agent that is acting outside his instructions or powers, only if ratifies the acts or the activity of the agent; otherwise, the agent remains liable for the acts concluded by himself.

The powers of the traditional agent are based upon the authority, that is either actual or apparent (as well as inherent or implied) and which embodies the source of the powers of the agent: consequently, the authority is the expression of the internal relationship between the principal and the agent. The representation, on the other hand, is the power of the agent that works in accordance to the Directive or the continental national regulations (including that of Romania) to represent the principal in relation to third parties, therefore being very similar to the powers of the intermediary/mandatory working on the basis of the mandate.

The modern concept of "authority", as core of the agency regulated by the Anglo-American laws, embraces and deals with both the principal's will and the act concluded by the agent, which are seen not as two independent and separate legal expressions or acts of distinct authors but rather as two sides of the same legal manifestation. Indeed, in the absence of the agent's involvement, there will be no internal relationship giving birth to the authority of the agent and no external relationship consisting of the act concluded by the agent with the third party; instead, these will be merged in a single act, concluded between the principal and the third party. This single act, when an agent is involved, is fragmented into the authorisation of the agent and the act concluded or the activity carried on by the agent. ${ }^{34}$ Therefore, the concept of authority is intrinsic to the nature of the agency.

On the other hand, in the continental laws, the agency is based on the concept of representation that is present but not inherent to a variety of contracts. For the civil law system representation is the legal mechanism while the contracts like the mandate or the agency are instruments that materialise this mechanism, i.e., the representation. Therefore, the representation is not of the essence, is not inherent to these contracts, being regulated separately, as a general rule of the legal acts, that may be concluded directly or through representation.

Therefore, the two institutions bearing the same name - the agency regulated by the English commercial law and the agency regulated by the continental regulations - are, notwithstanding, reflecting different concepts and are producing distinct effects, with the continental approach being yet very much influenced by the theory of the mandate (with or without representation). The above reviewed national

${ }^{34}$ Müller-Freienfels, W., Law of Agency, „The American Journal of Comparative Law” 6, no. 2/3 (1957): 165-88. Accessed February 10, 2021. doi:10.2307/837515. 
European law do not hesitate to characterise the agency as a form, a sub-specie of the mandate.

Therefore, in international agency contracts, the law governing the contract remains, thus far, very important for the determination of the extent of the agent's powers or for the assessment of the effects of the internal relationship that links the principal and the agent.

\section{Bibliography}

1. Albaric, Cristelle, Dickstein, Marianne, International Commercial Agency and Distribution Agreements: Case Law and Contract Clauses, Kluwer Law International B.V, 2017, Chapter XVI - Switzerland.

2. Baskind, Eric, Osborne, Greg, Roach Lee, Commercial Law, $3 \mathrm{r}^{\mathrm{d}}$ edition, Part. II: The Law of Agency, Oxford University PressPrint Publication, ISBN-13: 9780198825975.

3. Cozian, Maurice, Vivandier, Alain, Droit des sociétés, Cinquième Edition, Litec, 1992.

4. Dignam, Alan, Lowry, John, Company Law, Oxford University Press, 2006 pp. $255-256$.

5. Dobson, David. M., Gaudenzi, Rita, Agency and Distributorship Laws in Italy: Guidelines for the Foreign Principal, The International Lawyer, vol. 20, no. 3, American Bar Association.

6. Fiale, Aldo, Diritto Commerciale. XVII Edizione, Edizioni Giuridiche Simoni, 2006.

7. Groh, Dennis, German Commercial Agency Law at a Glance, Cologne, Germany, 2019/11/DAPJV-GAPLA.

8. Jausas, Augustin (editor), International Encyclopedia of Agency and Distribution Agreements, Wolters Kluwer Law \& Business, 2012.

9. Jenks, C. Wilfried, Human Rights and International Labor Standards, London: Stevens \& Sons; New York: Praeger, 1960, „American Journal of International Law”, 56(3), 880-881, Published online by Cambridge University Press.

10. Jimenez Sanchez, Guillermo J, Lecciones de Derecho Mercantil, Decimoquinta Edicion, Tecnos, 2012.

11. Markesinis, Basil, Munday, Roderick, Outline of the Law of Agency, $2^{\text {nd }}$ ed., London, 1986.

12. Martin, Elizabeth A. (editor), Oxford Dictionary of Law, Oxford University Press, 2003.

13. Müller-Freienfels, Wolfram, Legal Relations in the Law of Agency: Power of Agency and Commercial Certainty, „The American Journal of Comparative Law”, Volume 13, Issue 3, Summer 1964.

14. Reinhard, Yves, Thomasset-Pierre, Sylvie, Droit commercial. Actes de commerce. Commerçants. Fonds de commerce. Concurrence. Consommation., Litec, 2008.

15. Schmitthoff, Clive, Agency in International Trade. A study in Comparative Law, Hague Academy of International Law, 117, Recueil des Courts, 1970-1. 